\title{
Lựa chọn các kỹ thuật trồng nấm rơm của các nông hộ trồng nấm rơm ở Đồng bằng sông Cửu Long
}

\section{The choice of straw mushroom growing techniques of the straw mushroom growers in the Mekong Delta}

\author{
Phạm Thị Gấm Nhung ${ }^{*}$, Võ Thanh Danh ${ }^{1}$ \\ ${ }^{1}$ Trường Đại học Cần Thơ, Việt Nam \\ *Tác giả liên hệ, Email: uyennhung2011@gmail.com
}

THÔNG TIN

DOI: $10.46223 /$ HCMCOUJS. econ.vi.17.1.980.2021

Ngày nhận: 21/09/2020

Ngày nhận lại: 21/01/2021

Duyệt đăng: 01/04/2021

\section{Tù khóa:}

các kỹ thuật trồng nấm rơm; đồng bằng sông Cửu Long; nấm rơm; phân tích biên

Keywords:

mushroom growing techniques; straw Mekong Delta; straw mushroom; marginal analysis

\section{TÓM TẮT}

Bài viết phân tích việc lựa chọn các kỹ thuật trồng nấm rơm đạt hiệu quả kinh tế cao cho các nông hộ trồng nấm rơm ở Đồng bằng sông Cửu Long. Nghiên cứu được thực hiện dựa trên cơ sở phỏng vấn trực tiếp 115 nông hộ trồng nấm rơm tại huyện Lai Vung, tỉnh Đồng Tháp và quận Bình Thủy, quận Ô Môn, TP. Cần Thơ. Nghiên cứu sử dụng phương pháp phân tích biên để hỗ trợ các nông hộ trồng nấm rơm đưa ra quyết định lựa chọn kỹ thuật trồng nấm tối ưu. Các kỹ thuật trồng nấm rơm được phân tích bao gồm: sử dụng rơm, sử dụng meo, và sử dụng phân bón. Kết quả nghiên cứu cho thấy rằng để có được hiệu quả kinh tế cao trong trồng nấm rơm, các lựa chọn kỹ thuật ưu tiên nên áp dụng lần lượt là sử dụng rơm trong khoảng từ 20.0 đến $25.0 \mathrm{~kg} / \mathrm{m}^{2}$ (tương ứng $0.8-1.2$ cuộn $\mathrm{rơm} / \mathrm{m}^{2}$ ), sử dụng meo trong khoảng từ 1.1 bịch đến 2 bịch $/ \mathrm{m}^{2}$ và sử dụng phân bón trong khoảng từ 0.05 đến $0.19 \mathrm{~kg} / 100 \mathrm{~m}^{2}$.

ABSTRACT
The article aimed to analyze the choice of straw mushroom
growing techniques with the high economic efficiency of the
straw mushroom growers in the Mekong Delta. The study was
based on face-to-face interviews with 115 mushroom growing
households in Lai Vung District, Dong Thap Province, and Binh
Thuy District, O Mon District, Can Tho City. The study used
marginal analysis to help the straw mushroom growers decide on
choosing the optimal mushroom growing technique. The analyzed
techniques for growing straw mushrooms included: usage of
straw, usage of meow, and usage of fertilizers. The results
showed that, in order to achieve high economic efficiency in
mushroom production, the preferred techniques were to use the
amount of paddy straw ranging form 20.0 to $25.0 \mathrm{~kg} / \mathrm{m}^{2}$ (from 0.8
to 1.2 rolls of straw $/ \mathrm{m}^{2}$ ), the amount of meow ranging from 1.1
bags to $2 \mathrm{bags} / \mathrm{m}^{2}$ and the amount of fertilizers ranging from 0.05
to $0.19 \mathrm{~kg} / 100 \mathrm{~m}^{2}$.

\section{ABSTRACT} growing techniques with the high economic efficiency of the straw mushroom growers in the Mekong Delta. The study was based on face-to-face interviews with 115 mushroom growing households in Lai Vung District, Dong Thap Province, and Binh Thuy District, O Mon District, Can Tho City. The study used marginal analysis to help the straw mushroom growers decide on choosing the optimal mushroom growing technique. The analyzed techniques for growing straw mushrooms included: usage of straw, usage of meow, and usage of fertilizers. The results showed that, in order to achieve high economic efficiency in mushroom production, the preferred techniques were to use the amount of paddy straw ranging form 20.0 to $25.0 \mathrm{~kg} / \mathrm{m}^{2}$ (from 0.8 to 1.2 rolls of straw $/ \mathrm{m}^{2}$ ), the amount of meow ranging from 1.1 bags to $2 \mathrm{bags} / \mathrm{m}^{2}$ and the amount of fertilizers ranging from 0.05 to $0.19 \mathrm{~kg} / 100 \mathrm{~m}^{2}$. 


\section{Giới thiệu}

Nấm rơm là một trong những loại thực phẩm giàu dinh dưỡng (protein, chất béo, carbohydrates, chất xơ, ...), giàu khoáng chất (kali, natri, canxi và phốt pho), chứa nhiều loại Vitamin và đặc biệt có nhiều loại axit amin thiết yếu mà cơ thể không tổng hợp được (Verma, 2002).

Ở Việt Nam, việc nghiên cứu và sản xuất nấm ăn bắt đầu từ những năm 1970 thế kỷ trước đến nay đã làm chủ được công nghệ tạo giống, nuôi trồng, chế biến các loại nấm ăn và nấm dược liệu (H. P. Dinh, 2015). Nước ta có nhiều tiềm năng để phát triển sản xuất nấm ăn như nguồn nguyên liệu phong phú, nguồn lao động nông thôn dồi dào, thời tiết thuận lợi $(\mathrm{H}$. $\mathrm{H}$. Nguyen, Nguyen, Ngo, \& Nguyen, 2013). Ngành hàng nấm trở thành một ngành mạnh trong tỷ trọng giá trị sản xuất toàn ngành nông nghiệp.

Chính phủ đã ban hành Quyết định số 439/QĐ-TTg ngày 16/04/2012 phê duyệt Danh mục sản phẩm quốc gia thực hiện từ năm 2012 thuộc Chương trình phát triển sản phẩm quốc gia đến năm 2020. Căn cứ Quyết định trên, Bộ Nông nghiệp và Phát triển Nông thôn (2013) đã ban hành Quyết định số 2690/QĐ-BNN-KHCN ngày 12/11/2013 phê duyệt đề án khung phát triển sản phẩm quốc gia "Sản phẩm nấm ăn và nấm dược liệu" phục vụ chương trình phát triển sản phẩm quốc gia đến năm 2020 .

Theo Cục trồng trọt, cả nước ta sản xuất 16 loại nấm, trong đó các tỉnh phía Nam chủ yếu trồng nấm rơm, nấm mộc nhĩ; các tỉnh phía Bắc trồng nấm hương, nấm sò, nấm linh chi. Sản lượng nấm cả nước đạt hơn 250,000 tấn/năm. Kim ngạch xuất khẩu nấm đạt từ $25-30$ triệu USD, trong đó xuất khẩu nhiều nhất là nấm mộc nhĩ 120,000 tấn, nấm rơm 64,500 tấn, nấm sò 60,000 tấn, nấm linh chi 300 tấn (H. N. Nguyen \& Pham, 2013).

Vùng Đồng bằng sông Cửu Long có diện tích khoảng 40,816 km², dân số khoảng 17,660 nghìn người. Đồng bằng sông Cửu Long được coi là vựa lúa lớn nhất cả nước, với mật độ canh tác 02 vụ/năm và có vùng canh tác 03 vụ/năm, diện tích sản xuất lúa 4,241 nghìn ha, sản lượng lúa 23,831 nghìn tấn (Tổng cục thống kê, 2016) nên lượng rơm rạ trên đồng ruộng rất lớn, nhưng sau thu hoạch người nông dân có thói quen đốt rơm rạ, vùi rơm, trồng nấm, chăn nuôi, bán và cho người khác. Tuy nhiên hình thức đốt rơm rạ được nông dân chọn nhiều nhất, 98.23\% vụ Đông Xuân, 89.67\% vụ Hè Thu, 54.1\% vụ Thu Đông (Tran et al., 2014) trước khi làm vụ mùa mới.

Cách làm trên vừa gây lãng phí lớn vừa làm ô nhiễm không khí, gây hiệu ứng nhà kính từ đó gây ảnh hưởng xấu đến sản xuất nông nghiệp và gây hại cho sức khỏe của cộng đồng. Để hạn chế đốt rơm sau thu hoạch thì việc trồng nấm rơm là giải pháp tốt để sử dụng nguồn rơm rạ lớn ở Đồng bằng sông Cửu Long (Le \& Ngo, 2013).

Những năm qua tại nhiều địa phương ở Đồng bằng sông Cửu Long, người nông dân đã biết tận dụng nguồn rơm nguyên liệu để trồng nấm rơm. Do điều kiện tự nhiên thuận lợi cùng sự khuyến khích hỗ trợ của các ngành chức năng, nghề trồng nấm rơm đã tồn tại và phát triển khá bền vững, đáp ứng được nhu cầu thị trường, góp phần giải quyết việc làm, tăng thu nhập cho nông dân và giảm thiểu ô nhiễm môi trường.

Tuy nhiên hiệu quả sản xuất nấm rơm của các nông hộ ở Đồng bằng sông Cửu Long chưa cao và còn gặp nhiều khó khăn. Có nhiều nông hộ trồng nấm rơm phải chịu thua lỗ do nhiều nguyên nhân khác nhau như chất lượng rơm, meo không tốt hoặc hạn chế trong việc áp dụng kỹ thuật trong các khâu sản xuất nấm rơm, cách phối trộn và tỷ lệ phối trộn meo giống chưa hợp lý, hay cách sử dụng phân bón để ủ rơm, xử lý nền đất chưa hiệu quả, cách xếp mô chưa hợp lý. Để nâng cao hiệu quả kinh tế, các nông hộ trồng nấm rơm cần khắc phục những nguyên nhân trên và 
cần lựa chọn các kỹ thuật sản xuất nấm rơm tối ưu. Tuy nhiên các nông hộ trồng nấm rơm lại gặp khó khăn khi ra quyết định nên chọn kỹ thuật nào thích hợp và đem lại hiệu quả kinh tế cao? Bài viết là kết quả của việc phân tích lựa chọn các kỹ thuật trồng nấm rơm của các nông hộ sản xuất nấm rơm ở Đồng bằng sông Cửu Long nhằm tìm ra các giải pháp nâng cao hiệu quả kinh tế cho các nông hộ sản xuất nấm rơm ở Đồng bằng sông Cửu Long.

\section{2. Địa bàn và phương pháp nghiên cứu}

\section{1. Địa bàn và số liệu nghiên cứu}

Nghiên cứu sử dụng phương pháp chọn mẫu ngẫu nhiên để khảo sát các hộ trồng nấm rơm trên địa bàn hai tỉnh Cần Thơ và Đồng Tháp - địa phương có truyền thống trồng nấm rơm lâu năm, diện tích trồng nấm rơm lớn và đa dạng các mô hình trồng nấm rơm ngoài trời. Tại Cần Thơ có hai quận Ô Môn và Bình Thủy và tại Đồng Tháp có huyện Lai Vung được chọn để khảo sát. Tại mỗi quận, huyện tiến hành chọn các địa bàn (xã, phường) trồng nấm tập trung. Tại địa điểm khảo sát chọn bước nhảy $\mathrm{k}=2$ để chọn hộ tham gia khảo sát. Kết quả là có 115 hộ trồng nấm rơm tại hai tỉnh được chọn trả lời bảng hỏi khảo sát soạn sẵn bằng phần mềm cspro trên máy tính bảng. Cơ cấu mẫu điều tra hộ trồng nấm rơm được trình bày ở Bảng 1 .

\section{Bảng 1}

Cơ cấu mẫu điều tra hộ trồng nấm rơm

\begin{tabular}{lllcc}
\hline \multirow{2}{*}{ Tỉnh } & \multicolumn{1}{c}{ Huyện } & \multicolumn{1}{c}{ xã } & N & Phần trăm (\%) \\
\hline Đồng Tháp & & & 50 & 43.5 \\
& Lai Vung & Định Hòa & 20 & 17.4 \\
& Lai Vung & Phong Hòa & 10 & 8.7 \\
& Lai Vung & Tân Hòa & 20 & 17.4 \\
Cần Thơ & & & 65 & 56.5 \\
& Bình Thủy & Long Hòa & 6 & 5.2 \\
& Bình Thủy & Thới An Đông & 21 & 18.3 \\
& Ô Môn & Phước Thới & 9 & 7.8 \\
& Ô Môn & Thới Hưng & 22 & 19.1 \\
& Ô Môn & Trung Thành & 7 & 6.1 \\
Chung & & & 115 & 100.0 \\
\hline
\end{tabular}

Nguồn: Số liệu điều tra thực tế (2019)

Có 50 hộ trồng nấm ở 03 xã Định Hòa, Phong Hòa, Tân Hòa tại huyện Lai Vung, tỉnh Đồng Tháp được khảo sát. Có 65 hộ trồng nấm thuộc 02 phường Long Hòa, Thới An Đông tại quận Bình Thủy và 03 phường Phước Thới, Thới Hưng, Trung Thành tại quận Ô Môn, thành phố Cần Thơ được khảo sát.

\subsection{Phương pháp phân tích}

Nghiên cứu sử dụng phương pháp phân tích thống kê mô tả để mô tả thông tin mẫu khảo sát như số trung bình, độ lệch chuẩn, tần suất.

Để lựa chọn kỹ thuật sản xuất nấm rơm tối ưu cho các nông hộ trồng nấm rơm ở Đồng bằng sông Cửu Long, phương pháp phân tích biên được sử dụng.

Theo Perrin, Anderson, Winkelmann, và Moscardi (1988), Evans (2005), phân tích biên là một trình tự để tính tỷ suất lợi nhuận biên giữa các kỹ thuật, tiến hành theo từng bước từ kỹ 
thuật có chi phí thấp hơn đến chi phí cao hơn tiếp theo và so sánh tỷ suất lợi nhuận biên với tỷ suất lợi nhuận tối thiểu chấp nhận được để xác định kỹ thuật trồng nấm rơm hiệu quả nhất về mặt kinh tế.

Một kỹ thuật trồng nấm rơm được xem là triển vọng nhất khi mà một đồng lợi nhuận thu thêm được sẽ bằng mới một đồng chi phí bỏ thêm ra. Đó là, khi đối mặt với nhiều kỹ thuật trồng nấm rơm cần lựa chọn thì người trồng nấm rơm nên chọn những kỹ thuật trồng nấm rợm có chi phí thấp miễn là tỷ suất lợi nhuận biên lớn hơn một mức tỷ suất lợi nhuận kỳ vọng tối thiểu nào đó. Do đó, một kỹ thuật trồng nấm được khuyến cáo cho người sản xuất không chỉ dựa vào triển vọng của kỹ thuật đó mà còn phải thoả mãn đòi hỏi về hiệu quả kinh tế của mô hình đó.

Phương pháp phân tích biên được thực hiện qua 05 bước sau đây:

Bước 1: Xác định lợi ích ròng (Net benefits): Bước đầu tiên là xác định tất cả các biến có liên quan trong lựa chọn các kỹ thuật và tính toán tổng lợi ích ròng của các kỹ thuật và lợi ích ròng. Để xác định "lợi ích ròng" của các kỹ thuật khác nhau, đầu tiên phải tính toán "tổng lợi ích" và "tổng chi phí" trong chuyển đổi các kỹ thuật sản xuất. Lợi ích ròng của một kỹ thuật sản xuất được tính bằng cách trừ đi tổng chi phí từ tổng lợi ích;

Bước 2: Thực hiện phân tích loại trừ (Dominance Analysis): Điều này được thực hiện bằng cách phân loại các kỹ thuật, bao gồm cả các kỹ thuật sản xuất hiện tại, trên cơ sở chi phí, liệt kê chúng từ thấp nhất đến cao nhất, cùng với lợi ích ròng tương ứng. Khi di chuyển từ thấp nhất đến cao nhất, bất kỳ kỹ thuật có chi phí cao hơn nhưng có lợi ích ròng ít hơn được xem là "không hiệu quả" và có thể được loại trừ khỏi phân tích sau này;

Bước 3: Tính toán tỷ suất lợi nhuận biên (MRR - Marginal Rate of Return): Sau khi loại bỏ các kỹ thuật không hiệu quả, tỷ suất lợi nhuận biên giữa các kỹ thuật sẽ được tính toán. Căn cứ theo kỹ thuật phân tích tăng dần, bắt đầu từ kỹ thuật có chi phí thấp nhất đến kỹ thuật có chi phí tăng dần, tỷ lệ lợi nhuận biên được xác định bằng cách lấy lợi nhuận biên chia cho chi phí biên rồi nhân cho 100 ;

Bước 4: Xác định tỷ suất lợi nhuận tối thiểu (MARR - Minimum Acceptable Rate of Return): Kinh nghiệm và bằng chứng thực nghiệm cho thấy một tỷ lệ từ $50 \%$ đến $100 \%$ dường như là thích hợp. Nếu kỹ thuật là mới và đòi hỏi kỹ năng mới, tỷ lệ trên nên được sử dụng. Nếu kỹ thuật đơn giản hay chỉ là một sự điều chỉnh như thay đổi tỷ lệ bón phân khác nhau, tỷ lệ thấp hơn có thể chấp nhận được. Một phương pháp khác dùng để ước tính tỷ suất lợi nhuận tối thiểu là dựa trên mức gấp đôi lãi suất cho vay trên thị trường;

Bước 5: So sánh MRR với MARR: Nông dân sẽ sã̃n sàng chuyển đổi kỹ thuật trồng nấm miễn là tỷ suất lợi nhuận biên lớn hơn tỷ suất lãi tối thiểu. Do đó, các hộ nông dân trồng nấm rơm nên lựa chọn kỹ thuật trồng nấm có tỷ suất lợi nhuận biên cao hơn hoặc ít nhất bằng tỷ suất lợi nhuận tối thiểu.

\section{Kết quả và thảo luận}

\subsection{Tính chất mẫu điều tra nông hộ trồng nấm rơm}

Kết quả khảo sát 115 hộ trồng nấm cho thấy có hơn $91 \%$ đáp viên là nam. Tuổi của đáp viên trung bình là 42 tuổi. Trình độ học vấn trung bình của đáp viên là lớp 06 và cũng có người mù chữ. Số người trong hộ bình quân là $04-05$ người/hộ. Thu nhập bình quân/hộ/năm là trên 233 triệu đồng/hộ/năm (tương đương 4.5 triệu đồng/người/tháng). Có hơn $91 \%$ hộ trồng nấm có nguồn thu nhập chính từ nông nghiệp. Diện tích trồng nấm bình quân gần $1,140 \mathrm{~m}^{2} /$ hộ với chi phí thuê đất bình quân là 9.7 triệu đồng/hộ/năm. Có hơn $56 \%$ đất trồng nấm là đất nhà. Số vụ trồng nấm rơm trong năm trung bình là 08 vụ/năm. $100 \%$ hộ trồng nấm có tham gia các tổ chức, đoàn thể. Gần $20 \%$ hộ trồng nấm có tham gia các lớp tập huấn về trồng nấm rơm. 


\section{Bảng 2a}

Tính chất mẫu điều tra nông hộ trồng nấm rơm

\begin{tabular}{|c|c|c|c|c|c|}
\hline Chỉ tiêu & $\mathbf{N}$ & $\begin{array}{c}\text { Số } \\
\text { thấp nhất }\end{array}$ & $\begin{array}{c}\text { Số } \\
\text { cao nhất }\end{array}$ & $\begin{array}{c}\text { Số } \\
\text { trung bình }\end{array}$ & $\begin{array}{c}\text { Độ } \\
\text { lệch chuẩn }\end{array}$ \\
\hline Tuổi (năm) & 115 & 22 & 69 & 42.08 & 11.14 \\
\hline Số năm sống tại chỗ (năm) & 115 & 15 & 69 & 41.43 & 11.76 \\
\hline Trình độ học vấn (số năm đi học) & 115 & 0 & 12 & 6.42 & 2.68 \\
\hline Số người trong hộ (người) & 115 & 2 & 8 & 4.30 & 1.14 \\
\hline $\begin{array}{l}\text { Tổng thu nhập trong năm của hộ }(1,000 \\
\text { đồng) }\end{array}$ & 115 & 120 & $1,000.000$ & 233,618 & 187,485 \\
\hline Chi phí thuê đất/năm (1,000 đồng) & 115 & 0 & 80,000 & 9,686 & 13,961 \\
\hline $\begin{array}{l}\text { Chi phí thuê đất phân bổ cho vụ rồi } \\
(1,000 \text { đồng) }\end{array}$ & 115 & 0 & 8,000 & 1,136 & 15,167 \\
\hline Số vụ trồng trong năm (năm) & 115 & 3 & 12 & 8.06 & 2.91 \\
\hline Số lần tập huấn (lần) & 115 & 0 & 5 & 0.36 & 0.86 \\
\hline Diện tích trồng $\left(\mathrm{m}^{2}\right)$ vụ vừa rồi & 115 & 200 & 6,000 & $1,114.26$ & 852,62 \\
\hline $\begin{array}{l}\text { Tổng số lượng nấm thu hoạch }(\mathrm{kg}) \text { vụ } \\
\text { vừa rồi }\end{array}$ & 115 & 295 & 5,200 & 1,392 & 899,28 \\
\hline
\end{tabular}

Nguồn: Số liệu điều tra thực tế (2019)

\section{Bảng 2b}

Đặc điểm mẫu điều tra nông hộ trồng nấm rơm

\begin{tabular}{ccc}
\hline \multicolumn{1}{c}{ Chỉ tiêu } & $\mathbf{N}$ & Phần trăm (\%) \\
\hline Giới tính & 115 & 100.0 \\
Nam & 91 & 79.1 \\
Nữ & 24 & 20.9 \\
Tình trạng hôn nhân & 115 & 100.0 \\
Lập gia đình & 104 & 90.4 \\
Không & 11 & 9.6 \\
Nguồn thu nhập của hộ & 115 & 100.0 \\
Từ nông nghiệp & 105 & 91.3 \\
Phi nông nghiệp & 10 & 8.7 \\
Tham gia đoàn thể & 115 & 100.0 \\
Có tham gia & 3 & 2.6 \\
Không tham gia & 112 & 97.4 \\
Loại đất trồng nấm & 115 & 100.0 \\
Đất nhà & 65 & 56.5 \\
Đất thuê & 50 & 43.5 \\
Tham gia tập huấn & 115 & 100.0 \\
Có tham gia & 22 & 19.1 \\
Không tham gia & 93 & 80.9 \\
\hline
\end{tabular}

Nguồn: Số liệu điều tra thực tế (2019) 


\subsection{Lựa chọn kỹ thuật trồng nấm rơm}

Nghiên cứu sử dụng phương pháp phân tích biên để phân tích lựa chọn các kỹ thuật trồng nấm rơm đạt hiệu quả kinh tế cao nhất. Các kỹ thuật trồng nấm rơm được phân tích bao gồm: (i) sử dụng rơm, (ii) sử dụng meo, và (iii) sử dụng phân bón. Đối với yếu tố sử dụng thuốc BVTV, do tỷ lệ hộ sử dụng thuốc BVTV trong mẫu khảo sát thấp (dưới 20\%) nên không đưa vào trong nghiên cứu này. Kết quả phân tích thống kê mô tả trong Bảng 3, có 115 hộ trồng nấm cho thấy diện tích trồng nấm trung bình khoảng $1,114.26 \mathrm{~m}^{2} /$ hộ. Số lượng rơm sử dụng trung bình là 23.2 $\mathrm{kg} / \mathrm{m}^{2}$. Số bịch meo sử dụng trung bình là $1.47 \mathrm{bịch} / \mathrm{m}^{2}$. Số lượng phân bón trung bình là 0.28 $\mathrm{kg} / 100 \mathrm{~m}^{2}$. Tổng số lượng nấm rơm thu hoạch trung bình là $1,391.92 \mathrm{~kg}$. Năng suất nấm rơm trung bình đạt $1.34 \mathrm{~kg} / \mathrm{m}^{2}$. Giá bán nấm rơm tại thời điểm khảo sát tháng $05 / 2019$ trung bình là gần 43,000 đồng/kg.

\section{Bảng 3}

Thông tin trồng nấm rơm của hộ trồng nấm rơm

\begin{tabular}{|c|c|c|c|c|c|}
\hline Chỉ tiêu & $\mathbf{N}$ & $\begin{array}{c}\text { Số thấp } \\
\text { nhất }\end{array}$ & $\begin{array}{c}\text { Số cao } \\
\text { nhất }\end{array}$ & $\begin{array}{c}\text { Số trung } \\
\text { bình }\end{array}$ & $\begin{array}{c}\text { Độ lệch } \\
\text { chuẩn }\end{array}$ \\
\hline Diện tích trồng $\left(\mathrm{m}^{2}\right)$ vụ vừa rồi & 115 & 200 & 6,000 & $1,114.26$ & 852,61 \\
\hline Số $\mathrm{kg}$ rơm $/ \mathrm{m}^{2}$ & 115 & 18.0 & 32.0 & 23.20 & 3.95 \\
\hline Số bịch meo/m² & 115 & 0.8 & 3.2 & 1.47 & 0.65 \\
\hline Số lượng phân bón sử dụng $\left(\mathrm{kg} / 100 \mathrm{~m}^{2}\right)$ & 115 & 0.05 & 0.80 & 0.28 & 0.15 \\
\hline Tổng số lượng nấm thu hoạch (kg) & 115 & 295 & 5,200 & $1,391.92$ & 899,28 \\
\hline Năng suất $\left(\mathrm{kg} / \mathrm{m}^{2}\right)$ & 115 & 0.67 & 2.00 & 1.34 & 0.26 \\
\hline Giá bán $(1,000 đ / k g)$ & 115 & 30 & 55 & 42.62 & 7.39 \\
\hline Chi phí cơ hội của đất/m² (1,000 đồng) & 115 & 0.08 & 10.00 & 1.98 & 1.57 \\
\hline Chi phí rơm $\left(1,000 đ / m^{2}\right)$ & 115 & 18.00 & 32.00 & 23.20 & 3.95 \\
\hline Chi phí meo $\left(1,000 đ / \mathrm{m}^{2}\right)$ & 115 & 1.50 & 9.30 & 3.68 & 1.72 \\
\hline Chi phí phân bón $\left(1,000 đ / \mathrm{m}^{2}\right)$ & 115 & 0 & 0.08 & 0.02 & 6 \\
\hline Chi phí thuốc BVTV $\left(1,000 đ / m^{2}\right)$ & 115 & 0 & 0.50 & 0.03 & 0.078 \\
\hline Chi phí sản xuất - LĐ thuê $\left(1,000 đ / \mathrm{m}^{2}\right)$ & 115 & 3.00 & 18.20 & 4.02 & 2.609 \\
\hline Chi phí sản xuất - LĐ nhà (1,000đ/m2) & 115 & 4.39 & 25.27 & 10.22 & 4.39 \\
\hline Số ngày LĐ nhà-Thu hoạch nấm & 115 & 0 & 240 & 37.07 & 33.62 \\
\hline Số ngày LĐ thuê-Thu hoạch nấm & 115 & 0 & 100 & 23.16 & 17.20 \\
\hline Tổng số ngày LĐ (thuê và nhà) (ngày); trong đó: & 67 & 36 & 290 & 93.09 & 45.46 \\
\hline + Số ngày LĐ thuê (ngày) & 67 & 5 & 156 & 46.67 & 24.23 \\
\hline + Số ngày LĐ nhà (ngày) & 67 & 2 & 134 & 46.42 & 29.70 \\
\hline
\end{tabular}

Nguồn: Số liệu khảo sát thực tế (2019)

\subsubsection{Kỹ thuật 1: Sủ dụng rơm}

Theo kỹ thuật sử dụng rơm trong Bảng 4, có 03 nghiệm thức về số lượng rơm sử dụng được đánh giá lần lượt là: (i) nghiệm thức $1 \mathrm{~A}$ : từ 18.0 đến dưới $20.0 \mathrm{~kg} / \mathrm{m}^{2}$, (ii) nghiệm thức $1 \mathrm{~B}$ : từ 20.0 đến $25.0 \mathrm{~kg} / \mathrm{m}^{2}$, và (iii) nghiệm thức $1 \mathrm{C}$ : trên 25.0 đến $32.0 \mathrm{~kg} / \mathrm{m}^{2}$. Kết quả thống kê mô tả cho thấy rằng việc sử dụng nhiều rơm cho năng suất bình quân nấm rơm lần lượt theo từng mức độ sử dụng là $1.16 \mathrm{~kg} / \mathrm{m}^{2}, 1.36 \mathrm{~kg} / \mathrm{m}^{2}$, và $1.44 \mathrm{~kg} / \mathrm{m}^{2}$. 


\section{Bảng 4}

Các lựa chọn nghiệm thức và năng suất tương ứng

\begin{tabular}{clcc}
\hline Nghiệm thức & \multicolumn{1}{c}{ Nội dung } & Số hộ trồng nấm (hộ) & Năng suất bình quân $\left(\mathbf{k g} / \mathbf{m}^{\mathbf{2}}\right)$ \\
\hline 1A & Từ 18.0 đến dưới $20.0 \mathrm{~kg} / \mathrm{m}^{2}$ & 28 & 1.16 \\
1B & Từ 20.0 đến $25.0 \mathrm{~kg} / \mathrm{m}^{2}$ & 48 & 1.36 \\
1C & Trên 25.0 đến $32.0 \mathrm{~kg} / \mathrm{m}^{2}$ & 39 & 1.44 \\
\hline
\end{tabular}

Nguồn: Tổng hợp kết quả điều tra (2019)

Kết quả phân tích trong Bảng 5 cho thấy các nghiệm thức $1 \mathrm{~A}, 1 \mathrm{~B}, 1 \mathrm{C}$ có tổng lãi gộp (GM) lần lượt là 50,01 nghìn đồng $/ \mathrm{m}^{2} ; 57,46$ nghìn đồng $/ \mathrm{m}^{2} ; 61,29$ nghìn đồng $/ \mathrm{m}^{2}$; Tổng chi phí biến đổi (VC) lần lượt là 30,28 nghìn đồng $/ \mathrm{m}^{2} ; 35,48$ nghìn đồng $/ \mathrm{m}^{2} ; 44,11$ nghìn đồng $/ \mathrm{m}^{2}$; và lợi nhuận ròng $(\mathrm{NB})$ lần lượt là 19,73 nghìn đồng $/ \mathrm{m}^{2} ; 21,98$ nghìn đồng $/ \mathrm{m}^{2} ; 17,17$ nghìn đồng $/ \mathrm{m}^{2}$.

\section{Bảng 5}

Kết quả phân tích lợi nhuận ròng

\begin{tabular}{|c|c|c|c|c|}
\hline \multirow{3}{*}{ Chỉ tiêu } & \multirow{3}{*}{ Đơn vị tính } & \multicolumn{3}{|c|}{ Nghiệm thức } \\
\hline & & $\mathbf{1 A}$ & $1 B$ & $1 \mathrm{C}$ \\
\hline & & $\begin{array}{c}\text { Từ } 18.0 \text { đến dưới } \\
20.0 \mathrm{~kg} / \mathrm{m}^{2}\end{array}$ & $\begin{array}{l}\text { Từ } 20.0 \text { đến } \\
25.0 \mathrm{~kg} / \mathrm{m}^{2}\end{array}$ & $\begin{array}{c}\text { Trên } 25.0 \text { đến } \\
32.0 \mathrm{~kg} / \mathrm{m}^{2}\end{array}$ \\
\hline Năng suất trung bình & $\mathrm{kg} / \mathrm{m}^{2}$ & 1.16 & 1.36 & 1.44 \\
\hline Tổng lãi gộp (GM) & $1,000 \mathrm{~d} / \mathrm{m}^{2}$ & 50.01 & 57.46 & 61.29 \\
\hline Chi phí rơm & $1,000 \mathrm{~d} / \mathrm{m}^{2}$ & 18.63 & 22.07 & 27.86 \\
\hline Chi phí meo & $1,000 \mathrm{~d} / \mathrm{m}^{2}$ & 2.77 & 3.51 & 4.53 \\
\hline Chi phí phân bón & $1,000 \mathrm{~d} / \mathrm{m}^{2}$ & 0.01 & 0.02 & 0.02 \\
\hline Chi phí thuốc BVTV & $1,000 \mathrm{~d} / \mathrm{m}^{2}$ & 0.01 & 0.01 & 0.06 \\
\hline Chi phí lao động & $1,000 \mathrm{~d} / \mathrm{m}^{2}$ & 8.86 & 9.88 & 11.63 \\
\hline Tổng chi phí biến đổi (VC) & $1,000 \mathrm{~d} / \mathrm{m}^{2}$ & 30.28 & 35.48 & 44.11 \\
\hline Lợi nhuận ròng (NB) & $1,000 \mathrm{~d} / \mathrm{m}^{2}$ & 19.73 & 21.98 & 17.17 \\
\hline
\end{tabular}

Nguồn: Tổng hợp kết quả điều tra (2019)

Từ kết quả của phân tích loại trừ và tỷ suất lợi nhuận biên (MRR) được trình bày trong Bảng 6, tỷ suất lợi nhuận biên (MRR) của việc chuyển từ kỹ thuật 1 sang kỹ thuật 2 là 43.15\%. So sánh tỷ suất lợi nhuận biên và tỷ suất lợi nhuận tối thiểu (MARR), nghiệm thức $1 \mathrm{~B}$ sử dụng rơm từ 20.0 đến $25.0 \mathrm{~kg} / \mathrm{m}^{2}$ là nghiệm thức tối ưu mặc dù năng suất nấm thu được theo kỹ thuật này không phải là cao nhất so với Nghiệm thức $1 \mathrm{C}$.

\section{Bảng 6}

Kết quả phân tích loại trừ và tỷ suất lợi nhuận biên (MRR)

\begin{tabular}{|c|c|c|c|c|c|}
\hline \multirow[b]{2}{*}{ Nghiệm thức } & \multicolumn{2}{|c|}{ Chi phí biến đổi } & \multicolumn{2}{|c|}{ Lọii nhuận ròng } & \multirow{2}{*}{$\begin{array}{l}\text { Tỷ suất lệ } \\
\text { nhuận biên } \\
(\text { MRR) (\%) }\end{array}$} \\
\hline & $\begin{array}{c}\text { Tổng cộng } \\
(1,000 \text { d/m²) }\end{array}$ & $\begin{array}{l}\text { Chi phí biên } \\
(1,000 \text { đ/m²) }\end{array}$ & $\begin{array}{c}\text { Tổng cộng } \\
\left(1,000 \text { d/m } \mathbf{m}^{2}\right)\end{array}$ & $\begin{array}{c}\text { Lợi nhuận biên } \\
(1,000 \text { đ/m² }\end{array}$ & \\
\hline $1 \mathrm{~A}$ & 30.28 & - & 19.73 & - & - \\
\hline $1 \mathrm{~B}$ & 35.48 & 5.21 & 21.98 & 2.25 & 43.15 \\
\hline $1 \mathrm{C}$ & 44.11 & 8.63 & 17.17 & -4.80 & -55.67 \\
\hline
\end{tabular}

Nguồn: Tổng hợp kết quả điều tra (2019) 


\subsubsection{Kỹ thuật 2: Sủ dụng meo}

Theo kỹ thuật sử dụng meo trong Bảng 7, có 03 nghiệm thức về số lượng meo sử dụng được đánh giá lần lượt là: (i) nghiệm thức $2 \mathrm{~A}$ : từ dưới $1 \mathrm{bịch} / \mathrm{m}^{2}$, (ii) nghiệm thức $2 \mathrm{~B}$ : từ 1.1 bịch đến $2 \mathrm{bịch} / \mathrm{m}^{2}$, và (iii) nghiệm thức $2 \mathrm{C}$ : trên 2 bịch đến $3.2 \mathrm{bịch} / \mathrm{m}^{2}$. Kết quả thống kê mô tả cho thấy rằng việc sử dụng nhiều meo hơn cũng cho năng suất bình quân nấm rơm lần lượt theo từng mức độ sử dụng là $1.23 \mathrm{~kg} / \mathrm{m}^{2}, 1.34 \mathrm{~kg} / \mathrm{m}^{2}$, và $1.48 \mathrm{~kg} / \mathrm{m}^{2}$.

\section{Bảng 7}

Các lựa chọn nghiệm thức và năng suất tương ứng

\begin{tabular}{clcc}
\hline Nghiệm thức & \multicolumn{1}{c}{ Nội dung } & $\begin{array}{c}\text { Số hộ trồng nấm } \\
\text { (hộ) }\end{array}$ & $\begin{array}{c}\text { Năng suất bình quân } \\
\left(\mathbf{k g} / \mathbf{m}^{2} \mathbf{)}\right.\end{array}$ \\
\hline 2A & Dưới $01 \mathrm{bịch} / \mathrm{m}^{2}$ & 34 & 1.23 \\
2B & Từ 1.1 bịch đến $2 \mathrm{bịch} / \mathrm{m}^{2}$ & 58 & 1.34 \\
2C & Từ trên 02 bịch đến $3.2 \mathrm{bịch} / \mathrm{m}^{2}$ & 23 & 1.48 \\
\hline
\end{tabular}

Nguồn: Tổng hợp kết quả điều tra (2019)

Kết quả phân tích trong Bảng 8 , cho thấy các nghiệm thức $2 \mathrm{~A}, 2 \mathrm{~B}, 2 \mathrm{C}$ có tổng lãi gộp $(\mathrm{GM})$ lần lượt là 55,14 nghìn đồng $/ \mathrm{m}^{2}, 58,50$ nghìn đồng $/ \mathrm{m}^{2}, 54,69$ nghìn đồng $/ \mathrm{m}^{2}$; tổng chi phí biến đổi (VC) lần lượt là 33,86 nghìn đồng $/ \mathrm{m}^{2}, 36,17$ nghìn đồng $/ \mathrm{m}^{2}, 44,42$ nghìn đồng $/ \mathrm{m}^{2}$; và giá trị lợi nhuận ròng $(\mathrm{NB})$ lần lượt là 21,27 nghìn đồng $/ \mathrm{m}^{2}, 22,33$ nghìn đồng $/ \mathrm{m}^{2}, 10,26$ nghìn đồng/ $\mathrm{m}^{2}$.

\section{Bảng 8}

Kết quả phân tích lợi nhuận ròng

\section{Nghiệm thức}

Chỉ tiêu

Đơn vị tính

2A

2B

2C

dưới 01 Tù̀ 1.1 bịch đến Tù̀ trên 02 bịch

$\mathrm{bịch} / \mathrm{m}^{2} \quad 02 \mathrm{bịch} / \mathrm{m}^{2} \quad$ đến $3.2 \mathrm{bịch} / \mathrm{m}^{2}$

\begin{tabular}{lcccc}
\hline Năng suất trung bình & $\mathrm{kg} / \mathrm{m}^{2}$ & 1.23 & 1.34 & 1.48 \\
Tổng lãi gộp (GM) & $1,000 \mathrm{~d} / \mathrm{m}^{2}$ & 55.14 & 58.50 & 54.69 \\
Chi phí rơm & $1,000 \mathrm{~d} / \mathrm{m}^{2}$ & 22.74 & 22.60 & 25.36 \\
Chi phí meo & $1,000 \mathrm{~d} / \mathrm{m}^{2}$ & 2.13 & 3.46 & 6.51 \\
Chi phí phân bón & $1,000 \mathrm{~d} / \mathrm{m}^{2}$ & 0.01 & 0.02 & 0.03 \\
Chi phí thuốc BVTV & $1,000 \mathrm{~d} / \mathrm{m}^{2}$ & 0.01 & 0.01 & 0.08 \\
Chi phí lao động & $1,000 \mathrm{~d} / \mathrm{m}^{2}$ & 8.97 & 10.08 & 12.44 \\
Tổng chi phí biến đổi (VC) & $1,000 \mathrm{~d} / \mathrm{m}^{2}$ & 33.86 & 36.17 & 44.42 \\
Lợi nhuận ròng (NB) & $1,000 \mathrm{~d} / \mathrm{m}^{2}$ & 21.27 & 22.33 & 10.26 \\
\hline
\end{tabular}

Nguồn: Tổng hợp kết quả điều tra (2019) 
Từ kết quả của phân tích loại trừ và tỷ suất lợi nhuận biên (MRR) trong Bảng 9 , tỷ suất lợi nhuận biên (MRR) của việc chuyển từ kỹ thuật 1 sang kỹ thuật 2 là $45.65 \%$. So sánh tỷ suất lợi nhuận biên với tỷ suất lợi nhuận tối thiểu cho thấy nghiệm thức $2 \mathrm{~B}$ là lựa chọn tốt nhất trong số ba nghiệm thức, đem lại cho người trồng nấm là cao nhất khi sử dụng meo trong khoảng từ 1.1 bịch đến $02 \mathrm{bịch} / \mathrm{m}^{2}$ mặc dù năng suất nấm thu được theo kỹ thuật này không phải là cao nhất so với nghiệm thức $2 \mathrm{C}$.

\section{Bảng 9}

Kết quả phân tích loại trừ và tỷ suất lợi nhuận biên (MRR)

\section{Chi phí biến đổi Lội nhuận ròng}

\begin{tabular}{|c|c|c|c|c|c|}
\hline \multirow[b]{2}{*}{ Nghiệm thức } & & & \multirow{2}{*}{$\begin{array}{l}\text { Tỷ suất lọi nhuận } \\
\text { biên (MRR) (\%) }\end{array}$} \\
\hline & $\begin{array}{c}\text { Tổng cộng } \\
(1,000 \text { d/m² }\end{array}$ & $\begin{array}{l}\text { Chi phí biên } \\
(1,000 \text { d/m² }\end{array}$ & $\begin{array}{c}\text { Tổng cộng } \\
\left(1,000 \text { d/. } \mathbf{m}^{2}\right)\end{array}$ & $\begin{array}{l}\text { Lợi nhuận biên } \\
(1,000 \text { d/m²) }\end{array}$ & \\
\hline $2 \mathrm{~A}$ & 33.86 & - & 21.27 & - & - \\
\hline $2 \mathrm{~B}$ & 36.17 & 2.31 & 22.33 & 1.05 & 45.65 \\
\hline $2 \mathrm{C}$ & 44.42 & 8.25 & 10.26 & -12.06 & -146.15 \\
\hline
\end{tabular}

Nguồn: Tổng hợp kết quả điều tra (2019)

\subsubsection{Kỹ thuật 3: Sử dụng phân bón}

Theo kỹ thuật sử dụng phân bón trong Bảng 10, có 03 nghiệm thức về lượng phân bón sử dụng được đánh giá lần lượt là: (i) nghiệm thức $3 \mathrm{~A}$ : từ 0.05 đến $0.19 \mathrm{~kg} / 100 \mathrm{~m}^{2}$, (ii) nghiệm thức $3 \mathrm{~B}$ : từ 0.20 đến dưới $0.40 \mathrm{~kg} / 100 \mathrm{~m}^{2}$, và (iii) nghiệm thức $3 \mathrm{C}$ : từ $0.40 \mathrm{~kg} / 100 \mathrm{~m}^{2}$ trở lên. Kết quả thống kê mô tả cho thấy rằng việc sử dụng nhiều rơm cho năng suất nấm cao hơn lần lượt theo từng mức độ sử dụng là $1.24 \mathrm{~kg} / \mathrm{m}^{2}, 1.38 \mathrm{~kg} / \mathrm{m}^{2}$, và $1.32 \mathrm{~kg} / \mathrm{m}^{2}$.

\section{Bảng 10}

Các lựa chọn nghiệm thức và năng suất tương ứng

\begin{tabular}{clcc}
\hline Nghiệm thức & Nội dung & $\begin{array}{c}\text { Số hộ trồng nấm } \\
\text { (hộ) }\end{array}$ & $\begin{array}{c}\text { Năng suất bình } \\
\text { quân }\left(\mathbf{k g} / \mathbf{m}^{2}\right)\end{array}$ \\
\hline 3A & Từ 0.05 đến $0.19 \mathrm{~kg} / 100 \mathrm{~m}^{2}$ & 23 & 1.24 \\
3B & Từ 0.20 đến dưới $0.40 \mathrm{~kg} / 100 \mathrm{~m}^{2}$ & 67 & 1.38 \\
$3 \mathrm{C}$ & Từ $0.40 \mathrm{~kg} / 100 \mathrm{~m}^{2}$ trở lên & 25 & 1.32 \\
\hline
\end{tabular}

Nguồn: Tổng hợp kết quả điều tra (2019)

Kết quả phân tích trong Bảng 11, cho thấy các nghiệm thức $3 \mathrm{~A}, 3 \mathrm{~B}, 3 \mathrm{C}$ có tổng lãi gộp (GM) lần lượt là 55,64 nghìn đồng $/ \mathrm{m}^{2} ; 60,90$ nghìn đồng $/ \mathrm{m}^{2} ; 47,69$ nghìn đồng $/ \mathrm{m}^{2}$; tổng chi phí biến đổi (VC) lần lượt là 32,65 nghìn đồng $/ \mathrm{m}^{2} ; 37,41$ nghìn đồng/ $/ \mathrm{m}^{2} ; 40,54$ nghìn đồng $/ \mathrm{m}^{2}$; và giá trị lợi nhuận ròng $(\mathrm{NB})$ lần lượt là 22,99 nghìn đồng $/ \mathrm{m}^{2} ; 23,49$ nghìn đồng $/ \mathrm{m}^{2} ; 7,15$ nghìn đồng $/ \mathrm{m}^{2}$. 


\section{Bảng 11}

Kết quả phân tích lợi nhuận ròng

\begin{tabular}{|c|c|c|c|c|}
\hline \multirow{3}{*}{ Chỉ tiêu } & \multirow{3}{*}{ Đơn vị tính } & \multicolumn{3}{|c|}{ Nghiệm thức } \\
\hline & & $\mathbf{3 A}$ & 3B & $3 \mathrm{C}$ \\
\hline & & $\begin{array}{c}\text { Tù̀ } 0.05 \text { đến } \\
0.19 \mathrm{~kg} / 100 \mathrm{~m}^{2}\end{array}$ & $\begin{array}{c}\text { Từ } 0.20 \text { đến dưới } \\
0.40 \mathrm{~kg} / 100 \mathrm{~m}^{2}\end{array}$ & $\begin{array}{c}\text { Từ } 0.40 \mathrm{~kg} / 100 \mathrm{~m}^{2} \\
\text { trở lêen }\end{array}$ \\
\hline Năng suất trung bình & $\mathrm{kg} / \mathrm{m}^{2}$ & 1.24 & 1.38 & 1.32 \\
\hline Tổng lãi gộp (GM) & $1,000 \mathrm{~d} / \mathrm{m}^{2}$ & 55.64 & 60.90 & 47.69 \\
\hline Chi phí rơm & $1,000 \mathrm{~d} / \mathrm{m}^{2}$ & 22.94 & 22.85 & 24.36 \\
\hline Chi phí meo & $1,000 \mathrm{~d} / \mathrm{m}^{2}$ & 2.58 & 3.57 & 4.98 \\
\hline Chi phí phân bón & $1,000 \mathrm{~d} / \mathrm{m}^{2}$ & 0.01 & 0.01 & 0.04 \\
\hline Chi phí thuốc BVTV & $1,000 \mathrm{~d} / \mathrm{m}^{2}$ & 0.01 & 0.01 & 0.08 \\
\hline Chi phí lao động & $1,000 \mathrm{~d} / \mathrm{m}^{2}$ & 7.11 & 10.97 & 11.08 \\
\hline Tổng chi phí biến đổi (VC) & $1,000 \mathrm{~d} / \mathrm{m}^{2}$ & 32.65 & 37.41 & 40.54 \\
\hline Lợi nhuận ròng (NB) & $1,000 \mathrm{~d} / \mathrm{m}^{2}$ & 22.99 & 23.49 & 7.15 \\
\hline
\end{tabular}

Nguồn: Tổng hợp kết quả điều tra (2019)

Từ kết quả của phân tích loại trừ và tỷ suất lợi nhuận biên (MRR) được trình bày trong Bảng 12, tỷ suất lợi nhuận biên (MRR) của việc chuyển từ kỹ thuật 1 sang kỹ thuật 2 là 10.42\%; Tỷ suất lợi nhuận biên (MRR) của việc chuyển từ kỹ thuật 2 sang kỹ thuật 3 là $-522.91 \%$. Tỷ lệ này thấp so với tỷ suất lợi nhuận tối thiểu (MARR). Điều này cho thấy nghiệm thức $3 \mathrm{~A}$ là lựa chọn tốt nhất trong số ba nghiệm thức trong kỹ thuật 3 vì hai lựa chọn $3 \mathrm{~B}$ và $3 \mathrm{C}$ không đạt tỷ suất lợi nhuận tối thiểu mong muốn. Điều này cho thấy lợi ích đem lại cho người trồng nấm là cao nhất khi sử dụng phân bón trong khoảng từ 0.05 đến $0.19 \mathrm{~kg} / 100 \mathrm{~m}^{2}$ mặc dù năng suất nấm thu được theo kỹ thuật này là thấp nhất so với các kỹ thuật $3 \mathrm{~B}$ và $3 \mathrm{C}$.

\section{Bảng 12}

Kết quả phân tích loại trừ và tỷ suất lợi nhuận biên (MRR)

\begin{tabular}{cccccc}
\hline \multirow{2}{*}{ Nghiệm thức } & \multicolumn{2}{c}{ Chi phí biến đổi } & \multicolumn{2}{c}{ Lội nhuận ròng } & Tỷ suất lợi \\
& Tổng cộng & Chi phí biên & Tổng cộng & Lợi nhuận biên & $\begin{array}{c}\text { nhuận biền } \\
\text { (MRR) } \mathbf{\%})\end{array}$ \\
\hline 3A & 32.65 & - & 22.99 & - & - \\
3B & 37.41 & 4.76 & 23.49 & 0.50 & 10.42 \\
3C & 40.54 & 3.13 & 7.15 & -6.34 & -522.91 \\
\hline
\end{tabular}

Nguồn: Tổng hợp kết quả điều tra (2019)

Tóm lại, dựa trên các kết quả phân tích của ba kỹ thuật sử dụng rơm, meo, phân bón ở trên cho phép đề xuất các lựa chọn kỹ thuật ưu tiên lần lượt là kỹ thuật 1 (sử dụng rơm) chọn $1 \mathrm{~B}$ trong khoảng từ 20.0 đến $25.0 \mathrm{~kg} / \mathrm{m}^{2}$, kỹ thuật 2 (sử dụng meo) chọn $2 \mathrm{~B}$ trong khoảng từ 1.1 bịch đến 2 bịch $/ \mathrm{m}^{2}$, và kỹ thuật 3 (sử dụng phân bón) chọn $3 \mathrm{~A}$ trong khoảng từ 0.05 đến $0.19 \mathrm{~kg} / 100 \mathrm{~m}^{2}$.

\section{Kết luận và đề xuất}

Sản xuất nấm rơm ở huyện Lai Vung tỉnh Đồng Tháp và quận Bình Thủy, quận Ô Môn, TP. Cần Thơ đã mang lại thu nhập cho các nông hộ trồng nấm rơm, tạo việc làm cho các lao động nhàn rỗi ở địa phương sau khi mùa lúa và nâng cao mức sống cho người nông dân. Thu 
nhập bình quân/hộ/năm là trên 233 triệu đồng/hộ/năm (tương đương 4.5 triệu đồng/người/tháng). Có hơn $91 \%$ hộ trồng nấm có nguồn thu nhập chính từ nông nghiệp. Diện tích trồng nấm bình quân gần $1,140 \mathrm{~m}^{2} /$ hộ với chi phí thuê đất bình quân là 9.7 triệu đồng/hộ/năm. Số vụ nấm trồng trong năm trung bình là 08 vụ/năm.

Để nông hộ trồng nấm rơm có thu nhập cao từ việc trồng nấm, nghiên cứu sử dụng phương pháp phân tích biên để phân tích lựa chọn các kỹ thuật trồng nấm rơm đạt hiệu quả kinh tế cao nhất. Các kỹ thuật trồng nấm rơm được phân tích bao gồm: (i) sử dụng rơm, (ii) sử dụng meo, và (iii) sử dụng phân bón. Kết quả nghiên cứu cho thấy rằng để có được hiệu quả kinh tế cao trong trồng nấm rơm, các lựa chọn kỹ thuật ưu tiên nên áp dụng lần lượt là sử dụng rơm trong khoảng từ 20.0 đến $25.0 \mathrm{~kg} / \mathrm{m}^{2}$ (tương ứng $0.8-1.2$ cuộn $\mathrm{rơm} / \mathrm{m}^{2}$, sử dụng meo trong khoảng từ 1.1 bịch đến $2 \mathrm{bịch} / \mathrm{m}^{2}$, và sử dụng phân bón trong khoảng từ 0.05 đến $0.19 \mathrm{~kg} / 100 \mathrm{~m}^{2}$.

Tuy nhiên trong quá trình sản xuất nấm rơm của các nông hộ cũng gặp nhiều khó khăn do ảnh hưởng thời tiết, thiếu hiểu biết chất lượng rơm, chất lượng giống meo và hạn chế kỹ thuật trồng nấm. Có nhiều nông hộ sản xuất nấm rơm bị thua lỗ trong mùa vụ này.

Chính quyền địa phương cần liên kết với các nhà khoa học và người nông dân để tạo ra loại giống meo có chất lượng cao và tổ chức nhiều lớp tập huấn cho các nông hộ trồng nấm để họ có kiến thức về kỹ thuật trồng nấm cũng như có kiến thức về thị trường tiêu thụ.

Để phát triển nghề trồng nấm rơm có hiệu quả cao, các nông hộ nên chuyển đổi mô hình trồng nấm ngoài trời sang mô hình trồng nấm trong nhà vì trồng nấm trong nhà không chịu ảnh hưởng của thời tiết, tiết kiệm diện tích đất trồng, giảm chi phí công lao động và giảm chi phí rơm.

\section{LÒ̀I CÁM ƠN}

Nghiên cứu được thực hiện theo nhiệm vụ đề tài (mã số Đề tài: KHCN-TNB.ĐT/1419/C09) thuộc Chương trình Khoa học và Công nghệ phục vụ phát triển bền vững vùng Tây Nam bộ (mã số Chương trình: KHCN-TNB/14-19). Tác giả chân thành cám ơn Chương trình đã cấp kinh phí và hỗ trợ thực hiện nhiệm vụ đề tài này.

\section{Tài liệu tham khảo}

Bộ Nông nghiệp và Phát triển Nông thôn. (2013). Quyết định số 2690/QĐ-BNN-KHCN ngày 12/11/2013 phê duyệt đề án khung phát triển sản phẩm quốc gia "Sản phẩm nấm ăn và nấm duợc liệu” [Decision No. 2690/QĐ-BNN-KHCN dated November 12, 2013, on approving the national product development framework project "Edible and medicinal mushroom products"]. Retrieved June 15, 2020, from https://thuvienphapluat.vn/vanban/Linh-vuc-khac/Quyet-dinh-2690-QD-BNN-KHCN-2013-De-an-khung-phat-trien-sanpham-quoc-gia-nam-an-nam-duoc-lieu-213371.aspx

Dinh, H. P. (2003). Kinh tế nông nghiệp, lý thuyết và thực tiễn [Agricultural economics, theory and practice]. Ho Chi Minh City, Viet Nam: Nhà xuất bản Thống kê.

Dinh, L. X. (2015). Phát triển nấm - sản phẩm quốc gia [Development of mushroom-national products]. Retrieved May 20, 2020, from Nông nghiệp Việt Nam website: https://nongnghiep.vn/phat-trien-nam---san-pham-quoc-gia-d118596.html

Evans, E. A. (2005). Marginal analysis: An economic procedure for selecting alternative technologies/practices. Retrieved May 22, 2020, from Institute of Food and Agricultural Sciences, University of Florida website: https://edis.ifas.ufl.edu/publication/FE565

Le, T. V., \& Ngo, T. T. T. (2013). Hương phát triển trồng nấm rơm ở Đồng bằng sông Cưu Long: Thục trạng và giải pháp [Development direction of growing mushrooms in the 
Mekong Delta: Current situation and solutions]. Retrieved May 22, 2020, from Diễn đàn khuyến nông Phát triển nghề trồng nấm hiệu quả website: https://coa.ctu.edu.vn/khuyennong-khct/537-dien-dan-khuyen-nong-nong-nghiep-chuyen-de-phat-trien-nghe-trong-namhieu-qua.html

Nguyen, H. H., Nguyen, T. D., Ngo, N. T. B., \& Nguyen, M. T. (2013). Thưc trạng và giải pháp phát triển ngành nấm tại các tỉnh phía Nam [Situation and solutions for the development of the mushroom industry in the southern provinces]. Retrieved May 25, 2020, from http://iasvn.org/homepage/Thuc-trang-va-giai-phap-phat-trien-nganh-nam-tai-cac-tinhphia-Nam-7635.html

Nguyen, H. N., \& Pham, D. V. (2013). Thưc trạng và giải pháp phát triển sản xuất nấm tại các tinh phía Nam [Situation and solutions to develop mushroom production in the southern provinces]. Paper presented at Agriculture \& Rural Promotion Forum, 14th Efficient Mushroom Cultivation Theme, Vietnam.

Nguyen, Q. H., Nguyen, H. H., \& Le, P. V. (2018). Khảo sát phương pháp xếp mô và liều lượng meo đến sinh trưởng và năng suất nấm rơm (Volvariella volvacea) trong điều kiện ngoài trời [Examination of tissue mapping method and dose of meow to growth and yield of mushrooms (Volvariella volvacea) in outdoor conditions]. Tạp chí khoa học Truờng Đại hoc Cần Tho, 54, 98-105.

Perrin, R., Anderson, J., Winkelmann, D., \& Moscardi, E. (1988). From agronomic data to farmer recommendations: An economics training manual Centro International para el Mejoramiento de Maiz y Trigo Publ Mexico City. Retrieved May 27, 2020, from http://www.cimmyt.org

Thủ Tướng Chính phủ. (2012). Quyết định số 439/QĐ-TTg ngày 16/04/2012 phê duyệt Danh mục sản phẩm quốc gia thực hiện tù̀ năm 2012 thuộc Chuơng trình phát triển sản phẩm quốc gia đến năm 2020 [Decision No. 439/QD-TTg April 16, 2012 Approving the list of national products implemented from 2012 under the National Product Development Program to 2020]. Retrieved December 10, 2020, from https://thuvienphapluat.vn/lawviet-nam/search-document.aspx?keyword=439\%2fQ\%c4\%90-

$\mathrm{TTg}+\mathrm{ng} \% \mathrm{c} 3 \% \mathrm{a} 0 \mathrm{y}+16 \% 2 \mathrm{f04} \% 2 \mathrm{f} 2012 \&$ area $=0 \&$ match $=$ True \&type $=0 \&$ status $=0 \&$ signer $=0$ $\&$ sort $=1 \&$ lan $=2 \&$ scan $=0 \&$ fields $=\&$ org $=0$ \&page $=2$

Tổng cục Thống kê. (2016). Tình hình kinh tế xã hội năm 2016 [Socio-economic situation in 202016]. Retrieved December 27, 2018, from https://www.gso.gov.vn/nong-lam-nghiepva-thuy-san

Tran, N. S., Nguyen, N. T. H., Nguyen, C. H., Nguyen, N. V. C., Le, V. H., \& Ingvorsen, K. (2014). Uớc tính lượng và các biện pháp xử lý rơm rạ ở một số tỉnh Đồng bằng sông Cửu Long [Estimation of straw quantity and treatment methods in several provinces in the Mekong Delta]. Tạp chí Khoa học Truờng Đại học Cần Tho; Khoa học Tụ nhiên, Công nghệ và Môi trường, 32(2014), 87-93.

Verma, R. N. (2002). Cultivation of paddy straw mushroom (Volvariella spp.) In R. N. Verma \& B. Vijay (Eds.), Recent advances in the cultivation technology of edible mushrooms (pp. 221-228). Solan (HP), India: National Research Centre for Mushroom. 